\title{
Study on the Constraints of Animal Husbandry Farmers during Drought in Western Parts of Odisha, India
}

\author{
Devi Prasanna Swain ${ }^{1 *}$, Arunasis Goswami ${ }^{1}$, Bhabesh Chandra Das ${ }^{2}$, \\ Debasis Ganguli $^{1}$ and Madan Mohan Mahapatra ${ }^{3}$ \\ ${ }^{1}$ Department of Veterinary and Animal Husbandry Extension Education, \\ WBUAFS, Kolkata, India \\ ${ }^{2}$ Department of Veterinary and Animal Husbandry Extension Education, OUAT, Odisha, India \\ ${ }^{3}$ Department of Fisheries and Animal Resources Development, Govt. of Odisha, India \\ *Corresponding author
}

\section{A B S T R A C T}

\section{Keywords}

Drought, Odisha, Animal husbandry, constraints

Article Info

Accepted:

10 October 2019

Available Online:

10 November 2019
The present study was carried out to know the major constraints of animal husbandry farmers in drought prone western Odisha. A total of 72 respondents engaged in animal husbandry as primary occupation selected randomly from 3 district of western Odisha namely Bolangir, Kalahandi and Nuapad. The sampling method in selection of respondents became a stratified random sampling. During the study respondents stated that drought caused decrease in productivity of animals, affected Marketing facility for livestock and livestock products, threatened household food security as there was low production from animals were the $1^{\text {st }}$ three constraints in animal husbandry. According to the farmers interacted regarding animal husbandry constraints the rank order of the constraints were in the order of drought caused decrease in productivity of animals, affected marketing facility for livestock and livestock products, threatened household food security, distress sale of livestock and livestock products, drought affected cost of feed, diseases in animals which resulted in low production, drought affected schooling of children, reduction in household income, affected veterinary service delivery system, affected the social and psychological well being. But majority of the animal husbandry respondents stated that drought is not a severe threat to the animal husbandry farmers as they are not dependant on climatic variations.

\section{Introduction}

Livestock act as a significant remuneration to society in the terms of food, income, nutrients, employment, insurance, traction, clothing and others. Livestock is a major source of livelihood for most of the small and marginal farmers in India. As the income from crop production is not assured, in the absence of adequate land holdings, assured irrigation, timely supply of critical agricultural inputs and credit, along with these families maintain different species of livestock for their livelihood. However, most of them are not 
able to tap the potentials of these livestock due to various constraints. Livestock systems occupy $45 \%$ of the global surface area (Reid, et al., 2008) which serves as source of livelihoods globally. At the same time they are important providers of nutrients and traction for growing crops in smallholder systems (Thornton and Herrero, 2001). Livestock products contribute $17 \%$ to global kilocalorie consumption and $33 \%$ to protein consumption globally, but there are large differences between rich and poor countries (Rosegrant $e t$ al., 2009).

Farmers are confronting problems associated with unreliable rainfall and soils of low fertility, while animal keepers can adjust grazing patterns to their modified access to pasture and water and also can take nomadic method of living as well (Campbell, 1984). Impact of drought is related to social, economic, political factors as well as climatologically aspects (Campbell, 1984). A drought is a natural disaster of belowaverage precipitation in a given region; resulting in prolonged shortages in the water supply, whether atmospheric, surface water or ground water. In Odisha, western part is more dependent on the monsoon rain for the farming, and almost once in two years, this area faces the problem of either drought or drought like situation. Farmers in this region are either marginal or share croppers mostly, which makes them more venerable to this climatic calamities. Prolonged droughts results in mass migrations and humanitarian crisis. It can have a substantial impact on the ecosystem and agriculture of the affected region and harm to the local economy.

In India, frequency of drought is now increasing in Bihar, Uttar Pradesh, Karnataka, Kerala, Maharashtra, among a few other states. In nine out of past 15 years, about 100 districts of the country have witnessed a drought like-situation, triggered by failure of south-west monsoon. Keeping livestock is an important risk reduction strategy for vulnerable communities, as animals can act as insurance when required. Farm distress in Odisha worsened this when the kharif crop was severely impacted by scanty rainfall in July and August. According to the official records, crop area of 21.6 lakh ha is affected, out of which at least 14.82 lakh ha in 233 blocks in 27 districts have suffered losses over $33 \%$. The worst affected district is Mayurbhanj followed by Bargarh, Balangir, Keonjhar and Nayagarh districts. Odisha Govt. declared drought in nine districts of the state. Western Odisha districts lack irrigation facilities. Erratic monsoon destroys the crop leaving the farmer with nothing for sustenance and a mountain of debt that he is unable to repay (Special Relief commissioner's office, 01 Nov 2018.)

\section{Materials and Methods}

\section{Area under study and selection of respondents}

Western part of Odisha covers a numbers of districts viz. Sambalpur, Bargarh, Kalahandi, Nuapada, Bolangir, Sonepur, Deogarh, Jharsuguda and Sundargarh out of which, Balangir, Kalahandi and Nuapada face frequent droughts and simultaneously don't have any mechanism to provide livelihood activities to its populace at the time of drought. Most of the people (nearly 70\%) in these districts gain their livelihood out of agriculture, animal husbandry and agriculture labour. So these three districts are selected for the study purposively based on the findings as cited.

The research site (site of data collection) covered three blocks from these three districts that is one block from each district. Bangomunda block of Bolangir, Golamunda block of Kalahandi and Boden block of 
Nuapada are selected for data collection for the research work. These three blocks are proposed because, these blocks face severe drought and there is no other source of livelihood for the farmers. These blocks don't have any major irrigation project or any industry to provide livelihood to the farmers during drought. Moreover, these blocks lie adjacent to each other in a patch which will make the data collection more relevant and easier. Blocks are selected purposively.

During the study, 72 respondents were interacted from randomly from these 3 blocks namely, Bangomunda, Golamunda and Boden basing on their primary occupation of animal husbandry. So the sampling method in selection of respondents became a stratified random sampling.

\section{Preparation of the interview schedule}

On the basis of the pilot study and discussions with the stake holders and experts, the statements were framed. In the course of development of interview schedule, many proposed statements were discarded and new statements were added after judging each item with possible linkage as per the objective set forth in the study. Repeated verifications and proper measures were taken to avoid vague and ambiguous responses that may distort the information flow. Close ended questions were put in the schedule to get appropriate response.

Constraints of livelihood during drought in animal husbandry, agriculture and agricultural labour

Constrain means unnatural behaviour that is sometimes the result of forcing yourself to act in a particular way. Otherwise called as something that controls what you do by keeping you within particular limits. Droughts are common phenomena in many parts of
Western Odisha. Not only is the region drought-prone, but the rural communities inhabiting these areas are well aware of the adverse effects of droughts on their environment-dependent livelihoods. Small farmers, who are the most likely to experience disruptions to their production efforts, are even more vulnerable during droughts. There are many types of constraints face by the farmers during drought.

To study the constraints of livelihood during drought, different constraints are identified by having discussion with Professors, F\&ARD officials, beneficiaries and experts of Animal recourses Development department. The identified constraints were further validated by extension personnel. 10 statements related to constraints are randomly arranged in the questionnaire, and the respondents were asked to assign rank in order of most difficult one to least difficult one. The statement which was mentioned as highest constraint by the respondents is given rank 1 and the least is given 10. So in total, 10 statements were asked to the farmers according to their primary occupation. Constraints were ranked on the basis of Garrett's ranking technique.

\section{Data analysis}

Statistical measures provide the investigator with an opportunity of expressing the fact in an empirical way. The statistical measures employed in this study for interpretations of data are explained herewith Percentage, Rank Order and Garrett's ranking Technique. On the basis of the mean score, rank order was made. The item securing highest mean score was given first rank, next highest second rank and so on. It was assigned to items in roman numericals (I, II, III, IV ...).

To find out the most significant constraint which influences the respondent, Garrett's ranking technique was used. As per this 
method, respondents have been asked to assign the rank for all constraints and the outcome of such ranking has been converted into score value with the help of the following formula:

Percent position $=100(\mathrm{Rij}-0.5) / \mathrm{Nj}$

Where, $\mathrm{Rij}=$ Rank given for the ith variable by jth respondents

$\mathrm{Nj}=$ Number of variable ranked by $\mathrm{jth}$ respondents

With the help of Garrett's table, the percent position estimated is converted into scores. Then for each constraint, the scores of each individual are added and then total value of scores and mean values of score is calculated. The factors having highest mean value is considered to be the most important constraint and ranked 1st. the factors having lowest mean value is considered to be the least important constraint and ranked last.

\section{Results and Discussion}

There were so many constraints faced by the farmer which reduces the profit and hinders in the livelihood generation. An attempt was made to sum up 10 most important factors and rank them as per the farmer's opinion. Their responses are presented in the table 1-3.

The animal husbandry farmers were asked ten different questions related to the problems faced and which potentially reduces their livelihood generation during drought conditions. Each constraint was ranked as per their importance. On enquiring the extent of concern of Drought caused diseases in animals which resulted in low production, majority of respondents $(61.11 \%)$ rated as very low. This indicates that animal husbandry farmers don't think that drought has any severe impact on animal diseases ultimately resulting in reduced production. All most all the respondents $(93.06 \%)$ thought that extent of concern of Drought affected Veterinary service delivery system as the farmers were unable to afford the services is very low. On questioning the extent of concern on Drought threatened household food security as there was low production from animals, $8.33 \%$ respondents thought that the extent of concern was very severe, where as $9.72 \%$ thought it to be severe.

On asking the extent of concern of Drought affecting Marketing facility for livestock and livestock products, $62.50 \%$ respondents thought it of very low concern. $11.11 \%$ respondents thought that Drought caused Distress sale of livestock and livestock products as a very severe constraint, 6.94\% ranked as severe, $15.28 \%$ thought to be low and remaining $66.67 \%$ respondents ranked the same to be of low concern. $13.89 \%$ stated that extent of concern of Drought caused decrease in productivity of animals as very severe, whereas $11.11 \%$ responded as severe, whereas $55.56 \%$ thought it to be very low. Majority of respondents $(68.06 \%)$ opined that the extent of concern of Drought affecting the schooling of their children was very low suggesting that for animal husbandry farmers, drought has less impact

Majority of respondents engaged in animal rearing as primary occupation the opined that the extent of concern of drought to be very low suggesting that animal husbandry is somehow more stable to provide bread and butter to the farmers in drought affected areas and are more trustable in proving livelihood as compared to agriculture in drought affected area.

Reports suggested that, three most influential biophysical factors of drought vulnerability are: rainfall variability, drought intensity and shortage of available water holding capacity of 
soil where as three most influential socioeconomic factors are low irrigation development, poor crop insurance coverage and smaller forest area (Swain and Swain, 2011). In the study the primary constraint for animal husbandry responds were decrease in productivity of animals, Drought affected Marketing facility for livestock and livestock products and Drought threatened household food security as there was low production from animals respectively. Rainfall variability, soil type, land topography, groundwater availability and utilization, irrigation coverage, economic strength and institutional support system are some of the key factors that determine the nature and extent of drought vulnerability in a region (Swain and Swain, 2011). Udmale et al., (2014) reported that decrease in yield of cereals, horticultural crops, livestock production and loss of employment; all associated with decreased income of farmers, and were the most immediate economic impacts of drought. In developing countries, livestock production is mostly subsistence oriented and fulfils multiple functions that contribute more for livelihood security (Roessler et al., 2008; Duguma et al., 2010) probably due to the fact that they are less affected by climatic variations than agriculture practices.

Udmale et al., (2014) reported that decrease in yield of cereals, horticultural crops, livestock production and loss of employment all associated with decreased income of farmers were the most immediate economic impacts of drought. The nature and intensity of drought impacts vary from location to location, depending on relative influence of various agro-climatic, geophysical and socioeconomic factors (Swain and Swain, 2011). Karmee (2017) reported that with drought stalking districts of Nuapada, Balangir, Kalahandi and rain-fed areas of Bargarh, the peasants and marginal farmers have been robbed of their purchasing power. Karmee (2017) reported that with drought stalking districts of Nuapada, Balangir, Kalahandi and rain-fed areas of Bargarh, the peasants and marginal farmers have been robbed of their purchasing power.

Drought caused decrease in productivity of animals was ranked as I by the respondents (Table 2), whereas affected Marketing facility for livestock and livestock products, threatened household food security, distress sale of livestock and livestock products were ranked II, III, and IV, respectively as respondents. Drought affected cost of feed was ranked $\mathrm{V}$ by the respondents. Followed by, diseases in animals which resulted in low production, drought affected schooling of children, affected Veterinary service delivery system and affected the social and psychological well being as ranked as VI, VII, VIII, IX and X, Respectively.

Swain and Swain (2011) studied the nature of vulnerability to agricultural drought in three study blocks of Bolangir district in Western Odisha and documented that three most influential socioeconomic factors are: low irrigation development, poor crop insurance coverage and smaller forest area.

In drought prone western Odisha (Balangir, Kalahandi, and Nuapada districts), majority of the farmers opined that drought caused decrease in productivity of animals, affected Marketing facility for livestock and livestock products, threatened household food security as there was low production from animals were the $1^{\text {st }}$ three constraints in animal husbandry which affects the farmers to earn their livelihood. Most of the respondents opined that animal husbandry is not affected by climatic conditions like drought. 
Table.1

\begin{tabular}{|c|c|c|}
\hline SI. NO & Variable & Response \\
\hline $\mathbf{1}$ & Very Sever & 5 \\
\hline $\mathbf{2}$ & Sever & 4 \\
\hline $\mathbf{3}$ & Medium & 3 \\
\hline $\mathbf{4}$ & Less & 2 \\
\hline $\mathbf{5}$ & Very Less & 1 \\
\hline
\end{tabular}

Table.2 Response of respondents as per their constraints of livelihood during drought in animal husbandry

\begin{tabular}{|c|c|c|c|c|c|c|}
\hline \multirow{2}{*}{$\begin{array}{l}\text { Sl. } \\
\text { No }\end{array}$} & \multirow[t]{2}{*}{ Constraints } & \multicolumn{5}{|c|}{ Response } \\
\hline & & $\begin{array}{l}\text { Very } \\
\text { Severe }\end{array}$ & Severe & Moderate & Low & $\begin{array}{l}\text { Very } \\
\text { Low }\end{array}$ \\
\hline 1 & $\begin{array}{l}\text { Diseases in animals which } \\
\text { resulted in low production }\end{array}$ & $\begin{array}{c}4 \\
(5.56)\end{array}$ & $\begin{array}{c}5 \\
(6.94)\end{array}$ & $\begin{array}{c}5 \\
(6.94)\end{array}$ & $\begin{array}{c}14 \\
(19.44)\end{array}$ & $\begin{array}{c}44 \\
(61.11)\end{array}$ \\
\hline 2 & $\begin{array}{c}\text { Affected Veterinary service } \\
\text { delivery system }\end{array}$ & $\begin{array}{c}1 \\
(1.39)\end{array}$ & $\begin{array}{c}1 \\
(1.39)\end{array}$ & $\begin{array}{c}0 \\
(0.00)\end{array}$ & $\begin{array}{c}3 \\
(4.17)\end{array}$ & $\begin{array}{c}67 \\
(93.06)\end{array}$ \\
\hline 3 & $\begin{array}{l}\text { Threatened household food } \\
\text { security }\end{array}$ & $\begin{array}{c}6 \\
(8.33)\end{array}$ & $\begin{array}{c}7 \\
(9.72)\end{array}$ & $\begin{array}{c}3 \\
(4.17)\end{array}$ & $\begin{array}{c}12 \\
(16.67)\end{array}$ & $\begin{array}{c}44 \\
(61.11)\end{array}$ \\
\hline 4 & $\begin{array}{l}\text { Affected Marketing facility for } \\
\text { livestock and livestock products }\end{array}$ & $\begin{array}{c}8 \\
(11.11)\end{array}$ & $\begin{array}{c}7 \\
(9.72)\end{array}$ & $\begin{array}{c}1 \\
(1.39)\end{array}$ & $\begin{array}{c}11 \\
(15.28)\end{array}$ & $\begin{array}{c}45 \\
(62.50)\end{array}$ \\
\hline 5 & $\begin{array}{l}\text { Distress sale of livestock and } \\
\text { livestock products }\end{array}$ & $\begin{array}{c}8 \\
(11.11)\end{array}$ & $\begin{array}{c}5 \\
(6.94)\end{array}$ & $\begin{array}{c}0 \\
(0.00)\end{array}$ & $\begin{array}{c}11 \\
(15.28)\end{array}$ & $\begin{array}{c}48 \\
(66.67)\end{array}$ \\
\hline 6 & Drought affected cost of feed & $\begin{array}{c}7 \\
(9.72)\end{array}$ & $\begin{array}{c}6 \\
(8.33)\end{array}$ & $\begin{array}{c}2 \\
(2.78)\end{array}$ & $\begin{array}{c}7 \\
(9.72)\end{array}$ & $\begin{array}{c}50 \\
(69.44)\end{array}$ \\
\hline 7 & $\begin{array}{l}\text { Drought caused decrease in } \\
\text { productivity of animals }\end{array}$ & $\begin{array}{c}10 \\
(13.89)\end{array}$ & $\begin{array}{c}8 \\
(11.11)\end{array}$ & $\begin{array}{c}2 \\
(2.78)\end{array}$ & $\begin{array}{c}12 \\
(16.67)\end{array}$ & $\begin{array}{c}40 \\
(55.56)\end{array}$ \\
\hline 8 & $\begin{array}{l}\text { Drought affected schooling of } \\
\text { children }\end{array}$ & $\begin{array}{c}5 \\
(6.94)\end{array}$ & $\begin{array}{c}5 \\
(6.94)\end{array}$ & $\begin{array}{c}2 \\
(2.78)\end{array}$ & $\begin{array}{c}11 \\
(15.28)\end{array}$ & $\begin{array}{c}49 \\
(68.06)\end{array}$ \\
\hline 9 & $\begin{array}{l}\text { Drought caused reduction in } \\
\text { household income }\end{array}$ & $\begin{array}{c}5 \\
(6.94)\end{array}$ & $\begin{array}{c}4 \\
(5.56)\end{array}$ & $\begin{array}{c}1 \\
(1.39)\end{array}$ & $\begin{array}{c}10 \\
(13.89)\end{array}$ & $\begin{array}{c}52 \\
(72.22)\end{array}$ \\
\hline 10 & $\begin{array}{l}\text { Affected the social and } \\
\text { psychological well being }\end{array}$ & $\begin{array}{c}0 \\
(0.00)\end{array}$ & $\begin{array}{c}0 \\
(0.00)\end{array}$ & $\begin{array}{c}0 \\
(0.00)\end{array}$ & $\begin{array}{c}0 \\
(0.00)\end{array}$ & $\begin{array}{c}72 \\
(100.00)\end{array}$ \\
\hline
\end{tabular}

(The figures in upper row is frequency and lower is percentage in $3^{\text {rd }}, 4^{\text {th }}, 5^{\text {th }}, 6^{\text {th }}, 7^{\text {th }}$ columns) 
Table.3 Rank order of Constraints of generating livelihood from animal husbandry during drought

\begin{tabular}{|c|l|c|c|}
\hline $\begin{array}{c}\text { Sl. } \\
\text { No }\end{array}$ & \multicolumn{1}{|c|}{ Constraints } & \multicolumn{2}{|c|}{ Response } \\
\cline { 3 - 4 } & & $\begin{array}{c}\text { Mean } \\
\text { Score }\end{array}$ & $\begin{array}{c}\text { Rank } \\
\text { Order }\end{array}$ \\
\hline $\mathbf{1}$ & Diseases in animals which resulted in low production & 1.76 & VI \\
\hline $\mathbf{2}$ & Affected Veterinary service delivery system & 1.14 & IX \\
\hline $\mathbf{3}$ & Threatened household food security & 1.88 & III \\
\hline $\mathbf{4}$ & Affected Marketing facility for livestock and livestock products & 1.92 & II \\
\hline $\mathbf{5}$ & Distress sale of livestock and livestock products & 1.81 & IV \\
\hline $\mathbf{6}$ & Drought affected cost of feed & 1.79 & V \\
\hline $\mathbf{7}$ & Drought caused decrease in productivity of animals & 2.11 & I \\
\hline $\mathbf{8}$ & Drought affected schooling of children & 1.69 & VII \\
\hline $\mathbf{9}$ & Drought caused reduction in household income & 1.61 & VIII \\
\hline $\mathbf{1 0}$ & Affected the social and psychological well being & 1.00 & X \\
\hline & Total Mean score & 16.71 \\
\hline
\end{tabular}

\section{References}

Campbell, D.J., 1984. Response to drought among farmers and herders in southern Kajiado District, Kenya. Human Ecology, 12(1), pp.35-64.

Duguma, G., Mirkena, T., Haile, A., Iñiguez, L., Okeyo, A.M., Tibbo, M., Rischkowsky, B., Sölkner, J. and Wurzinger, M., 2010. Participatory approaches to investigate breeding objectives of livestock keepers. Livestock Research for Rural Development. Volume 22, Article \#64. Retrieved April 5, from http://www.lrrd.org/lrrd22/4/dugu2206 4.htm

Karmee S., 2017. Kosal Discussion and Development Forum. https:// kddfonline.com/author/sanjibkarmee/

Reid, R.S., Galvin, K.A. and Kruska, R.S., 2008. Global significance of extensive grazing lands and pastoral societies: an introduction. In Fragmentation in semi-arid and arid landscapes: Consequences for Human and Natural Systems. Edited by Galvin KA (pp. 1-
24). Springer, Dordrecht.

Roessler, R., Drucker, A.G., Scarpa, R., Markemann, A., Lemke, U., Thuy, L.T. and Zarate, A.V., 2008. Using choice experiments to assess smallholder farmers' preferences for pig breeding traits in different production systems in North-West Vietnam. Ecological economics, 66(1), pp.184-192.

Rosegrant, M.W., Fernandez, M., Sinha, A., Alder, J., Ahammad, H., Fraiture, C.D., Eickhour, B., Fonseca, J., Huang, J., Koyama, O. and Omezzine, A.M., 2009. Looking into the future for agriculture and AKST (agricultural knowledge science and technology). In Agriculture at a Crossroads. Edited by McIntyre BD, Herren HR, Wakhungu J, Watson RT. Island Press; 2009:307376.

Swain, M. and Swain, M., 2011. Vulnerability to agricultural drought in Western Orissa: A case study of representative blocks. Agricultural Economics Research Review, 24, pp.47-56.

Thornton, P.K. and Herrero, M., 2001. 
Integrated crop-livestock simulation models for scenario analysis and impact assessment. Agricultural Systems, 70(2-3), pp.581-602.

Udmale, P., Ichikawa, Y., Manandhar, S., Ishidaira, H. and Kiem, A.S., 2014.
Farmers' perception of drought impacts, local adaptation and administrative mitigation measures in Maharashtra State, India. International Journal of Disaster Risk Reduction, 10, pp.250-269.

\section{How to cite this article:}

Devi Prasanna Swain, Arunasis Goswami, Bhabesh Chandra Das, Debasis Ganguli and Madan Mohan Mahapatra. 2019. Study on the Constraints of Animal Husbandry Farmers during Drought in Western Parts of Odisha. Int.J.Curr.Microbiol.App.Sci. 8(11): 1022-1029. doi: https://doi.org/10.20546/ijcmas.2019.811.120 